\title{
Parietal Cell Vagotomy
}

National Cancer Institute

\section{Source}

National Cancer Institute. Parietal Cell Vagotomy. NCI Thesaurus. Code C94442.

Surgical denervation of the body and fundus of the stomach. 